Original Research Article

\title{
Study on antipyretic property of the leaves of Ligustrum robustum
}

\author{
Vanlalhruaii ${ }^{1}$, Naveen P. $^{2 *}$
}

${ }^{1}$ Department of Pharmacology, ${ }^{2}$ Department of Physiology, Mizoram Institute of Medical Education and Research (MIMER), Falkawn, Aizawl, Mizoram, India

Received: 23 August 2018

Revised: 27 August 2018

Accepted: 30 August 2018

\section{*Correspondence to:}

Dr. Naveen P.,

Email: naveenphysiol@ gmail.com

Copyright: (C) the author(s), publisher and licensee Medip Academy. This is an openaccess article distributed under the terms of the Creative Commons Attribution NonCommercial License, which permits unrestricted noncommercial use, distribution, and reproduction in any medium, provided the original work is properly cited.

\begin{abstract}
Background: Thorough pharmacological experiments on various plants used in traditional medicines are in progress in order to establish their effectiveness and safety. But modern drugs or conventional medicines are often viewed as impersonal, emphasizing crisis intervention. Keeping in view the above idea, the present study is undertaken on the plant Ligustrum robustum to explore its antipyretic property in albino rats.

Methods: Healthy young albino rats weighing between 100-250gm were obtained for the study. The animals were divided into five groups with six animals in each group. Pyrexia was induced by subcutaneous injection of dried yeast in $2 \%$ gum acacia in normal saline at a dose of $20 \mathrm{ml} / \mathrm{kg}$ body weight below the nape of the neck in albino rats. The antipyretic activity of the aqueous extract of Ligustrum robustum was tested by yeast induced method. The data were subjected to ANOVA followed by Dunnett's ' $t$ ' test for statistical significance between different groups.

Results: Ligustrum robustum in doses of $100 \mathrm{mg} / \mathrm{kg}, 200 \mathrm{mg} / \mathrm{kg}$ and $400 \mathrm{mg} / \mathrm{kg}$ significantly reduced the temperature ( $p<0.05$ to 0.01 ) in the $3^{\text {rd }}$ and $4^{\text {th }}$ hour after drug administration.

Conclusions: Present study concludes that the aqueous extract of the leaves of Ligustrum robustum showed significant antipyretic property in the standard experimental animal models.
\end{abstract}

Keywords: Antipyretics, Albino rat, Ligustrum robustum

\section{INTRODUCTION}

It is well known that traditional herbal medication existed since before the application of modern scientific method of health care, and today majority of world population depends on herbal care practices, particularly those living in villages. ${ }^{1}$ These drugs are invariable single plant extracts or from different plants extracts or fractions thereof or mixture of fraction/extracts from different plants. $^{2}$

The practices of using medicinal plants incorporated ancient beliefs and were passed on from one generation to another by oral and/or guarded literature. Although effective in the treatment of various ailments, very often these drugs are unscientifically exploited and/or improperly used. Therefore, these plants drugs deserve detailed studies in the light of modern science. ${ }^{3}$ In the last decade WHO, recognizing the importance of herbal medicines, had passed many resolutions for improving the quality and efficacy of plant drugs. ${ }^{1}$

Fever (Pyrexia) is defined as an elevation of core body temperature above the level maintained by the individual, with a mean value of $98.6^{\circ} \mathrm{F}\left(37^{\circ} \mathrm{C}\right)$ the normal 'set point'. ${ }^{4}$ A common feature of fever is the enhanced formation of cytokines such as IL- $1 \beta$ IL- 6 , interferon $\alpha$ and $\beta$ and TNF $\alpha$. The cytokines, increase the synthesis of $\mathrm{PGE}_{2}$ in circumventricular organs in and near to the pre-optic hypothalamic area, and $\mathrm{PGF}_{2}$, via increases in cAMP 
trigger the hypothalamus to elevate body temperature by promoting increase in heat generation and decrease in heat loss. ${ }^{5}$

Ligustrum robustum (Figure 1) is a common medium sized tree or shrub. A full-grown plant is about 30 feet high and 3 feet girth. Bark is quite smooth, pale brown in colour. Twigs are densely lenticelatte. Young shoots pubescent. Leaves 2-4 x 1-1.5 inches, ovate-lanceolate or elliptic, usually narrow at both ends, sometimes acuminate, glabrous; lateral nerves indistinct 5-8 pairs, with smaller ones in between. ${ }^{6}$

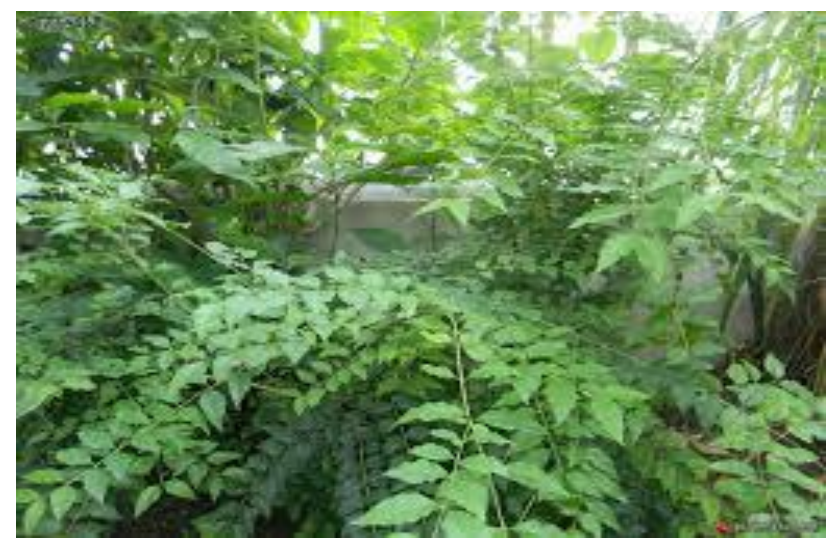

Figure 1: Leaves of Ligustrum robustum.

Ligustrum robustum is found abundantly in Manipur. It is also found scattered throughout the state of Tripura and distributed from Assam to Bangladesh, Myanmar and Malaysia. It is found abundant near the base of the hills. The plant Ligustrum robustum crushed leaves has been used for inflammatory gland swelling, skin infections. The leaves were boiled, and watery extract is given for treatment of acute gouty arthritis in Manipur.

The present study has been undertaken to evaluate the antipyretic action/property of the aqueous extract of the leaves of Ligustrum robustum on albino rat as compared to standard drugs.

\section{METHODS}

The aqueous extract of Ligustrum robustum was prepared by the methods of Rao SK et al, and Khosla P et al, with slight modifications. ${ }^{7,8} 50 \mathrm{gm}$ of powdered leaves were extracted with soxhlet apparatus with $500 \mathrm{ml}$ of distilled water till the eluent was colourless. The water extract was evaporated, scraped out, weighed and stored in a glazed porcelain jar for use. The yield was $18.83 \%$ and percentage of solubility of the extract was $0.6 \%$.

On preliminary chemical investigation the aqueous extract of Ligustrum robustum was subjected to qualitative chemical test as described by Kokate CK, for the detection of phytoconstituents. ${ }^{9}$ Preliminary studies with $5 \%$ dilute ferric chloride, $25 \%$ basic lead acetate solution and
Wagner's reagent, showed the presence of flavonoids, phenolic compounds and tannins in the extract.

Healthy albino rats were obtained from the Central Animal House, Regional Institute of Medical Sciences (RIMS), Imphal, Manipur, India for the study. Ethical clearance was obtained from Ethical Committee.

The antipyretic activity of the aqueous extract of Ligustrum robustum was tested by yeast induced method of Brownlee as described by Burn JH et al. ${ }^{10}$

\section{Materials}

Albino rats were used in the study. Drugs which were used, Aspirin (manufactured by USV LTD, Mumbai), test drug (Ligustrum robustum was prepared by the methods of Rao SK et al, and Khosla P et al, dried yeast, distilled water, gum acacia present in department of Pharmacology, RIMS were used for the study. ${ }^{7,8}$ Digital clinical thermometer, feeding tube, syringe, rat holder, marking pen.

Healthy young albino rats of either sex weighing between $100-250 \mathrm{gm}$ with a normal temperature of $98-99.6^{\circ} \mathrm{F}$ (constant for 7 days observation) were used for the study. The animals were maintained on a standard laboratory diet until approximately 2 hours before the administration of the drug, food was withdrawn but the animals had access to water ad libitum. The temperature of the room during the study was $22-25^{\circ} \mathrm{C}$. After measuring the basal rectal temperature, animals were given subcutaneous injection of $2 \%$ gum acacia in normal saline at a dose of $20 \mathrm{ml} / \mathrm{kg}$ below the nape of the neck.

After 19 hours of yeast injection, animals were restrained in individual cages for recording their rectal temperatures. Rectal temperatures were measured by inserting a digital clinical thermometer to a constant depth of $3 \mathrm{~cm}$. After recording the temperature, the animals were grouped into five groups of six animals each (Table 1).

Table 1: Grouping of animals (control, test and standard) and drug administration respectively.

\begin{tabular}{|ll|}
\hline Group & Drug \\
\hline Control & Normal saline \\
\hline Test A & L. robustum $(100 \mathrm{mg} / \mathrm{kg})$ \\
\hline Test B & L. robustum $(200 \mathrm{mg} / \mathrm{kg})$ \\
\hline Test C & L. robustum $(400 \mathrm{mg} / \mathrm{kg})$ \\
\hline Standard & Aspirin $(100 \mathrm{mg} / \mathrm{kg})$ \\
\hline
\end{tabular}

The drugs were suspended in $2 \%$ gum acacia and administered orally. The volumes of medicaments were kept constant at $10 \mathrm{ml} / \mathrm{kg}$ body weight of the animals.

Temperatures were recorded at hourly intervals up to 23 hours after yeast injection. The data were subjected to ANOVA followed by Dunnett's ' $t$ ' test for statistical significance between different groups. 


\section{RESULTS}

Table 2 shows the anti-pyretic effect of the aqueous extract of Ligustrum robustum leaves on dried yeast induced pyrexia in albino rats. There was no significant difference ( $p$ >0.05) between mean initial basal temperatures of different groups. After 19 hours of the injection of yeast subcutaneously, there was significant rise of temperature in the Control group 101.06 \pm 0.24 (p >0.00.1), Test A $100.50 \pm 0.20$ ( $\mathrm{p}<0.001)$, Test B $100.50 \pm 0.54$ ( $\mathrm{p}<0.001)$, Test C $100.07 \pm 0.14(\mathrm{p}<0.001)$ and the Standard group $100.50 \pm 0.15(p<0.001)$ respectively in comparison to the initial basal temperature in each group (Figure 2). However, there was no significant difference between the mean temperatures $(\mathrm{p}<0.05)$ in between the groups.

Table 2: Antipyretic activity of aqueous extract of Ligustrum robustum on dried yeast induced pyrexia in albino rats.

\begin{tabular}{|c|c|c|c|c|c|c|c|}
\hline \multirow[b]{2}{*}{ Group } & \multirow{2}{*}{$\begin{array}{l}\text { Dose } \\
\mathrm{mg} / \mathrm{kg} \text {, } \\
\mathrm{p.o.} \\
10 \mathrm{ml} / \mathrm{kg} \\
\end{array}$} & \multirow{2}{*}{$\begin{array}{l}\text { Initial basal } \\
\text { Rectal temp. } \\
\left({ }^{\circ} \mathbf{F}\right) \\
(\text { Mean } \pm \text { SEM })\end{array}$} & \multirow{2}{*}{$\begin{array}{l}\text { Temp. after } \\
\text { 19hrs of } \\
\text { induction }\left({ }^{\circ} \mathrm{F}\right) \\
(\text { Mean } \pm \text { SEM })\end{array}$} & \multicolumn{4}{|c|}{ Temperature after treatment $\left({ }^{\circ} \mathbf{F}\right)($ Mean \pm SEM) } \\
\hline & & & & $1^{\text {st }} \mathrm{Hr}$. & $2^{\text {nd }} \mathrm{Hr}$. & $3^{\text {rd }} \mathrm{Hr}$. & $4^{\text {th }} \mathrm{Hr}$. \\
\hline Control & $10 \mathrm{ml}$ & $99.05 \pm 0.13$ & $101.06 \pm 0.24$ & $101 \pm 0.22$ & $100.9 \pm 0.3$ & $100.6 \pm 0.3$ & $100.9 \pm 0.27$ \\
\hline A (Test) & 100 & $98.70 \pm 0.08$ & $100.50 \pm 0.20$ & $100.5 \pm 0.18$ & $100.1 \pm 0.06$ & $99.9 \pm 0.06^{*}$ & $99.8 \pm 0.08 \perp$ \\
\hline $\mathrm{B}$ (Test) & 200 & $98.90 \pm 0.10$ & $100.50 \pm 0.54$ & $100.5 \pm 0.54$ & $100.3 \pm 0.11$ & $99.8 \pm 0.03 *$ & $99.7 \pm 0.04 \perp$ \\
\hline $\mathrm{C}$ (Test) & 400 & $99.25 \pm 0.05$ & $100.07 \pm 0.14$ & $100.07 \pm 0.14$ & $100.3 \pm 0.21$ & $99.8 \pm 0.11 *$ & $99.6 \pm 0.06 \perp$ \\
\hline Standard & 100 & $99.00 \pm 0.15$ & $100.50 \pm 0.15$ & $100.50 \pm 0.20^{*}$ & $99.9 \pm 0.14 *$ & $99.8 \pm 0.13 *$ & $99.6 \pm 0.14 \perp$ \\
\hline $\begin{array}{l}\text { One-way } \\
\text { ANOVA }\end{array}$ & $\begin{array}{l}F(d f) \\
p\end{array}$ & $\begin{array}{l}2.34(4,25) \\
\text { NS }\end{array}$ & $\begin{array}{l}1.698(4,25) \\
\text { NS }\end{array}$ & $\begin{array}{l}2.87(4,25)^{*} \\
<0.05\end{array}$ & $\begin{array}{l}3.61(4,25)^{*} \\
<0.01\end{array}$ & $\begin{array}{l}8.56(4,25)^{*} \\
<0.001\end{array}$ & $\begin{array}{l}12.72(5,25)^{*} \\
<0.0001\end{array}$ \\
\hline
\end{tabular}

Values are mean \pm SEM; $n=6$ in each group; ${ }^{p} p<0.05$, when compared to control at that particular hour; $\perp$ p $<0.01$, when compared to control at that particular hour

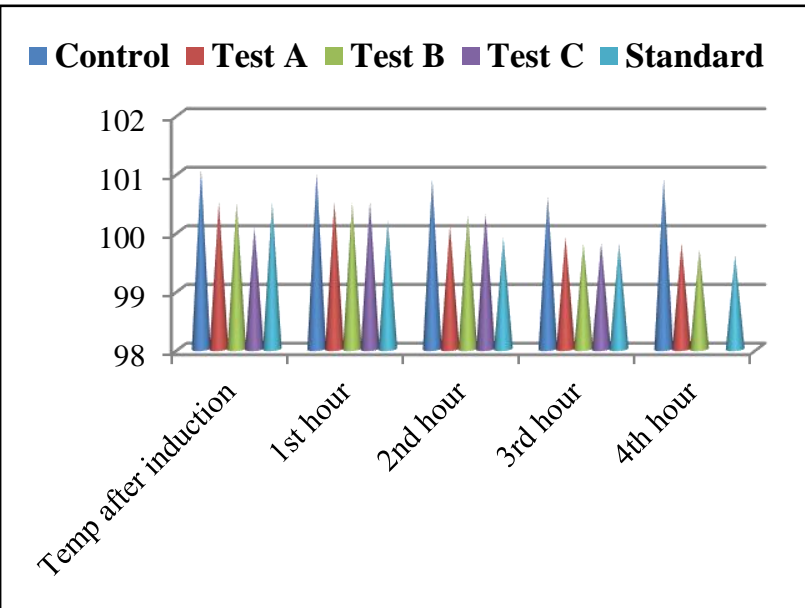

Figure 2: Anti-pyretic effect of the aqueous extract of Ligustrum robustum leaves on dried yeast induced pyrexia in albino rats.

The reduction of the mean temperature in aspirin treated group at $1^{\text {st }}, 2^{\text {nd }}, 3^{\text {rd }}$ and $4^{\text {th }}$ hour was $100.5 \pm 0.20(\mathrm{p}<0.05)$, 99.9 \pm 0.14 ( $\mathrm{p}<0.01), 99.8 \pm 0.13(\mathrm{p}<0.05), 99.6 \pm 014(\mathrm{p}$ $<0.01$ ) respectively when compared to values of the control group at corresponding hours (Table 2).

The temperatures recorded with the test A drug $(100 \mathrm{mg} / \mathrm{kg}$ p.o.) at $1^{\text {st }}, 2^{\text {nd }}, 3^{\text {rd }}$ and $4^{\text {th }}$ hours were $100.5 \pm 0.18$, $100.1 \pm 0.06,99.9 \pm 0.06,99.8 \pm 0.08(\mathrm{p}<0.01)$ respectively (Figure 2, Table 2). The mean temperature for the test $\mathrm{B}$ drug $(200 \mathrm{mg} / \mathrm{kg}, \mathrm{p.o})$ at the $1^{\text {st }}, 2^{\text {nd }}, 3^{\text {rd }}$ and $4^{\text {th }}$ hours were
$100.5 \pm 0.04,100.3 \pm 0.11,99.8 \pm 0.03(\mathrm{p}<0.05), 99.7 \pm 0.04(\mathrm{p}$ $<0.01$ ) respectively (Table 2 , Figure 2 ).

In the test drug $\mathrm{C}(400 \mathrm{mg} / \mathrm{kg}$, p.o.), mean temperatures were found to be $100.5 \pm 0.14,100.3 \pm 0.21,99.8 \pm 0.11$ $(\mathrm{p}<0.05), 99.6 \pm 0.06(\mathrm{p}<0.01)$ at $1^{\text {st }}, 2^{\text {nd }}, 3^{\text {rd }}$ and $4^{\text {th }}$ hour respectively (Figure 2). The figures within parenthesis show the degree of significance when compared to values of the control group at the respective hours (Table 2).

\section{DISCUSSION}

The antipyretic activity of the aqueous extract of Ligustrum robustum leaves was studied by the yeast induced method of Brownlee et al, with slight modification. ${ }^{10}$ In the present study, subcutaneous injection of $2 \%$ aqueous suspension of dried yeast in gum acacia was used at a dose of $20 \mathrm{ml} / \mathrm{kg}$ below the nape of the neck of the albino rats. ${ }^{11}$

The initial basal temperature of various group of pyretic rats in present study ranged from $98.7 \pm 0.08$ to $99.2 \pm 0.05^{\circ} \mathrm{F}$ which is in conformity with the findings of Gupta MB et al. ${ }^{12}$ The rise in temperature after 19 hours of induction was between $100.5 \pm 0.15$ to $101.06 \pm 0.24^{0} \mathrm{~F}$ which is similar to the findings of Mukherjee PK et al. ${ }^{13}$ There was no significant difference between the mean temperature of the different groups and the mean temperature after 19 hours of pyrexia (Table 2). The test drug Ligustrum robustum in concentrations of $100 \mathrm{mg} / \mathrm{kg}, 200 \mathrm{mg} / \mathrm{kg}$ and $400 \mathrm{mg} / \mathrm{kg} \mathrm{did}$ not reduce the body temperature of pyretic rats till the $2^{\text {nd }}$ hour. But significant reduction of temperature was observed at $3^{\text {rd }}$ hour and $4^{\text {th }}$ hour $(\mathrm{p}<0.01)$ respectively. 
Aspirin $(100 \mathrm{mg} / \mathrm{kg})$ lowered the rectal temperature of pyretic rats significantly from the $1^{\text {st }}$ hour to 4 th hour ( $p$ $<0.05$ to 0.01 ). In the control group, the mean rectal temperature of the pyretic rats was more or less maintained throughout the study period (Table 2 ).

The results of the present study show that the aqueous extract of Ligustrum robustum possesses antipyretic activity in dried yeast induced elevation of body temperature in rats. No signs of adverse effects were noticed following treatment with aqueous Ligustrum robustum at doses of 100, 200 and $400 \mathrm{mg} / \mathrm{kg}$ in rats.

Trease GE et al, and Rajnarayana $\mathrm{K}$ et al, reported that some flavonoids are predominant inhibitors of either cyclooxygenase or lipooxygenase. ${ }^{14,15}$ The antipyretic effect of the aqueous extract of Ligustrum robustum could be due to the presence of flavonoid compounds. Hajare SW et al, demonstrated the antipyretic activity of Dalbergia sissoo leaves, fever was induced by injecting $20 \mathrm{ml} / \mathrm{kg}$ s.c of $20 \%$ suspension of Brewer's yeast in normal saline below the nape of neck of albino rats. ${ }^{11}$ Mutalik $\mathrm{S}$ et al, demonstrated the antipyretic effects of Solanum melangena Linn, pyrexia was induced by injecting $20 \%$ (w/v) aqueous suspension of Brewer's yeast. ${ }^{16}$ Aspirin is a non-steroidal anti-inflammatory drug (NSAID) reset the thermostat. The mechanism of the antipyretic action of the NSAIDs is thought to be largely due to inhibition of prostaglandin production in the hypothalamus. ${ }^{17}$

\section{CONCLUSION}

Ligustrum robustum exhibited significant antipyretic effect upto $4^{\text {th }}$ hour of drug administration in albino rats. Aqueous extract of Ligustrum robustum showed the presence of flavonoids, phenolic compounds and tannins in the extract. The antipyretic effect of the aqueous extract of Ligustrum robustum is due to the presence of flavonoid compounds.

Funding: No funding sources

Conflict of interest: None declared

Ethical approval: The study was approved by the Institutional Ethics Committee

\section{REFERENCES}

1. Subramoniam A. The problems and prospects of plant drug research in India. Pharmacological evaluation of ecotypes in herbal drug development. Indian $\mathbf{J}$ Pharmacol. 2001 May 1;33(3):145.

2. Dev S. Ethnotherapeutics and modern drug development: the potential of Ayurveda. Current Sci. 1997 Dec 10;73(11):909-28.

3. Subramoniam A, Pushpangadan P. Development of phytomedicines for liver disease. Indian J Pharmacol. 1999 May 1;31(3):166-75.

4. Beutler B and Beutler BS. The Pathogenesis of fever, Cecil Text book of medicine, Bennett JC and Plum F.
W.S. Saunders Company, 20 ${ }^{\text {th }}$ Ed. Philadelphia; 1996;1533-1535.

5. Roberts II LJ and Morrow JD. Analgesic-antipyretic and anti-inflammatory agents and drugs employed in the treatment of gout, Goodman and Gilman's; The pharmacological basis of therapeutics, Joel G. Hardman and Lee Limbird: Mc Graw Hill, $10^{\text {th }} \mathrm{Ed}$, New York; 2001:687-732.

6. Osmaston AE. Oleaceae, Ligustrum robustum, A forest flora for kumaon: Bishen Singh, Mahendra Pal Singh, Dehra Dun;1978:340-341.

7. Rao SK, Mishra SH. Antiinflammatory and hepatoprotective activities of Sida rhombofolia Linn. Indian J Pharmacol. 1997;29:110-6.

8. Khosla P, Sangeeta B, Singh J, Srivastava RK. Antinociceptive activity of Azadirachta indica (neem) in rats. Indian J Pharmacol. 2000 Nov 1;32(6):372-4.

9. Kokate CK. Practical Pharmacognosy. $4^{\text {th }}$ Ed, Vallabh Prakashan, New Delhi;1994:4-29.

10. Burn JH, Finney DJ and Goodwin LG: Antipyretics and analgesics, Biological standardization, Geoffrey Cumberlege. Amen House, London EC-4. 1952;2:325-31.

11. Hajare SW, Chandra S, Tandan SK, Sarma J, Lal J, Telang AG. Analgesic and antipyretic activities of Dalbergia sissoo leaves. Indian J Pharmacol. 2000 Nov 1;32(6):357-60.

12. Gupta MB, Palit TK, Singh N, Bhargava KP. Pharmacological studies to isolate the active constituents from Cyperus rotundus possessing antiinflammatory, anti-pyretic and analgesic activities. Indian J Med Res. 1971 Jan;59(1):76.

13. Mukherjee PK, Das J, Saha K, Giri SN, Pal M, Saha BP. Antipyretic activity of Nelumbo nucifera rhizome extract. Indian J Experimental Biol. 1996 Mar;34(3):275-6.

14. Trease GE and Evans WC: Phenolic compounds and tannins, Pharmacognosy; Bailliere Trindall, $4^{\text {th }}$ Ed, London; 1972:146-148.

15. Narayana KR, Reddy MS, Chaluvadi MR, Krishna DR. Bioflavonoids classification, pharmacological, biochemical effects and therapeutic potential. Indian J Pharmacol. 2001 Feb;33(1):2-16.

16. Mutalik S, Paridhavi K, Rao CM, Udupa N. Antipyretic and analgesic effect of leaves of Solanum melongena Linn. in rodents. Indian J Pharmacol. 2003 Sep 1;35(5):312-5.

17. Rang HP, Dale MM and Ritter JM: Anti-inflammatory and immunosuppressant drugs, pharmacology: Churchill Livingstone, $4^{\text {th }}$ Ed, New York; 1999:229247.

Cite this article as: Vanlalhruaii, Naveen P. Study on antipyretic property of the leaves of Ligustrum robustum. Int J Basic Clin Pharmacol 2018;7:186972. 